\title{
Large-Scale Spatial and Temporal Variability of Larval Fish Assemblages in the Tropical Atlantic Ocean
}

\author{
CHRISTIANE S. DE SOUZA and PAULO O. MAFALDA JUNIOR
}

\author{
Universidade Federal da Bahia, Instituto de Biologia, \\ Laboratório de Plâncton, Rua Ademar de Barros, s/n, Ondina, 40210-020 Salvador, BA, Brazil \\ Manuscript received on July 28, 2017; accepted for publication on April 30, 2018
}

\begin{abstract}
How to cite: SOUZA CS AND JUNIOR POM. 2019. Large-Scale Spatial and Temporal Variability of Larval Fish Assemblages in the Tropical Atlantic Ocean. An Acad Bras Cienc 91: e20170567. DOI 10.1590/00013765201820170567.
\end{abstract}

\begin{abstract}
This study investigated the large-scale spatial and temporal variability of larval fish assemblages in the west tropical Atlantic Ocean. The sampling was performed during four expeditions. Identification resulted in 100 taxa (64 families, 19 orders and 17 suborders). During the four periods, 80\% of the total larvae taken represented eight characteristics families (Scombridae, Carangidae, Paralepididae, Bothidae, Gonostomatidae, Scaridae, Gobiidae and Myctophidae). Fish larvae showed a rather heterogeneous distribution with density at each station ranging from 0.5 to 2000 larvae per $100 \mathrm{~m} 3$. A general trend was observed, lower densities at oceanic area and higher densities in the seamounts and islands. A gradient in temperature, salinity, phytoplankton biomass, zooplankton biomass and station depth was strongly correlated with changes in ichthyoplankton structure. Myctophidae, and Paralepididae presented increased abundance at high salinities and temperatures. Bothidae and Gobiidae were more abundant at higher phytoplankton biomass and zooplankton biomass. Scaridae, Scombridae and Gonostomatidae had higher abundances at deep offshore stations. Different events might be responsible for the formation, maintenance and breakdown of fish larvae assemblage in the tropical oceanic area of Brazil. The results suggested that the oceanographic variables (temperature, salinity, phytoplankton biomass, zooplankton biomass and station depth) played an important role on the distribution patterns of ichthyoplankton.
\end{abstract}

Key words: Abiotic and biotic interactions, abundance, distribution, ichthyoplankton.

\section{INTRODUCTION}

Ichthyoplankton studies play a key role in the understanding of the ecology and evolution of fish fauna and their constituent populations (Moser and Smith 1993). Demand for knowledge on the distribution and abundance of ichthyoplankton

Correspondence to: Christiane Sampaio de Souza

E-mail: chsampaio@ig.com.br

ORCid: http://orcid.org/0000-0002-3331-014X has increased in fishery research to complement independent stock assessments and help predict fisheries yields (Lessa et al. 1999).

It is known that larval fish assemblages result from adult spawning strategies and environmental influences (Franco-Gordo et al. 2002). An understanding of the recruitment process requires knowledge of their small, medium and largescale distributions in relation to abiotic and biotic parameters (Röpke 1993). 
Variations in oceanographic conditions may result in changes in fish community structure due to the effect that this change would have on the abundance and species composition associated with it (Whitfield and Paterson 2003).

The area covered in the present study consists of continental shelf, slope and deep seamounts and islands, which represent the main regional sites for commercial and artisanal fisheries, yielding almost all the fish caught in the open oceanic area of North-Eastern Brazil (Travasso et al. 1999). It could be expected that each of these different systems would have an impact on productivity and fish communities in the oceanic waters.

In the continental shelf and slope, continental runoff and coastal wind-induced upwelling play an important role in ichthyoplankton species composition (Lopes et al. 2006, Muhling et al. 2008). The role of seamounts and oceanic islands in fishery production is well known to fishermen, since they cause remarkable concentrations of commercially valuable species, as a result of the enhancement process (Fonteneau 1991).

Knowledge of abiotic and biotic interactions in these environments are important for a greater understanding of functioning and conservation of the spawning area as well as the recruitment processes and the overall dynamics of fish populations.

In our study, temporal and spatial changes in the fish larvae assemblages were examined to test the hypothesis that the large-scale distribution of ichthyoplankton in the west tropical Atlantic Ocean is associated with oceanographic conditions (temperature, salinity, phytoplankton biomass, zooplankton biomass and station depth).

\section{MATERIALS AND METHODS}

The samples for this study were collected during the Revizee Projects aboard the ANTARES oceanographical ship. A total of 562 samples were collected during four expeditions. The study area comprised the tropical oceanic region between
0 and $14^{\circ} \mathrm{S}$ and 28 and $42^{\circ} \mathrm{W}$ (Figure 1). The expeditions were made on August - October of 1995 (Period 1), January - April of 1997 (Period 2), April - July of 1998 (Period 3) and September - December of 2000 (Period 4). Ichthyoplankton samples were collected by Bongo nets with $50 \mathrm{~cm}$ - diameter mouth, 500 and $300 \mu \mathrm{m}$ meshes, but only the ichthyoplankton collected with $500 \mu \mathrm{m}$ net were considered in this study. The nets were equipped with two independent flowmeters. Flowmeters were fitted in the mouth of each net to determine the amount of water filtered per tow.

The sampling method used was described by Smith and Richardson (1977). Sampling was done through oblique hauls with duration of 10 minutes. Sampling depth of the tows ranged from $5 \mathrm{~m}$ above the bottom at shallow stations, to $200 \mathrm{~m}$ at offshore stations. The samples obtained were preserved in $4 \%$ buffered formalin - seawater. In the laboratory, all larvae were removed from each sample and stored in $70 \%$ alcohol. The larvae were identified according to the morphological characters of each group and classified in relation to habitat of adult fish groups by Moyle and Cech Jr (1982) and Nelson (1994). Standard densities of individual taxa were expressed as the number per $100 \mathrm{~m}^{3}$ of filtered water for each collection.

Temperature and salinity were recorded by CTD. Seawater samples for the analysis of phytoplanktonic biomass (chlorophyll $a$ ) were collected using Nisken Bottles. Chlorophyll $a$ analysis was carried out spectrophotometrically using methods developed from Strickland and Parsons (1972). The determination of the zooplanktonic biomass (dry weight) was carried through according to the methodology of Omori and Ikeda (1984).

\section{DATA ANALYSIS}

Maps of the horizontal distribution were made using SURFER for Windows package of Golden 


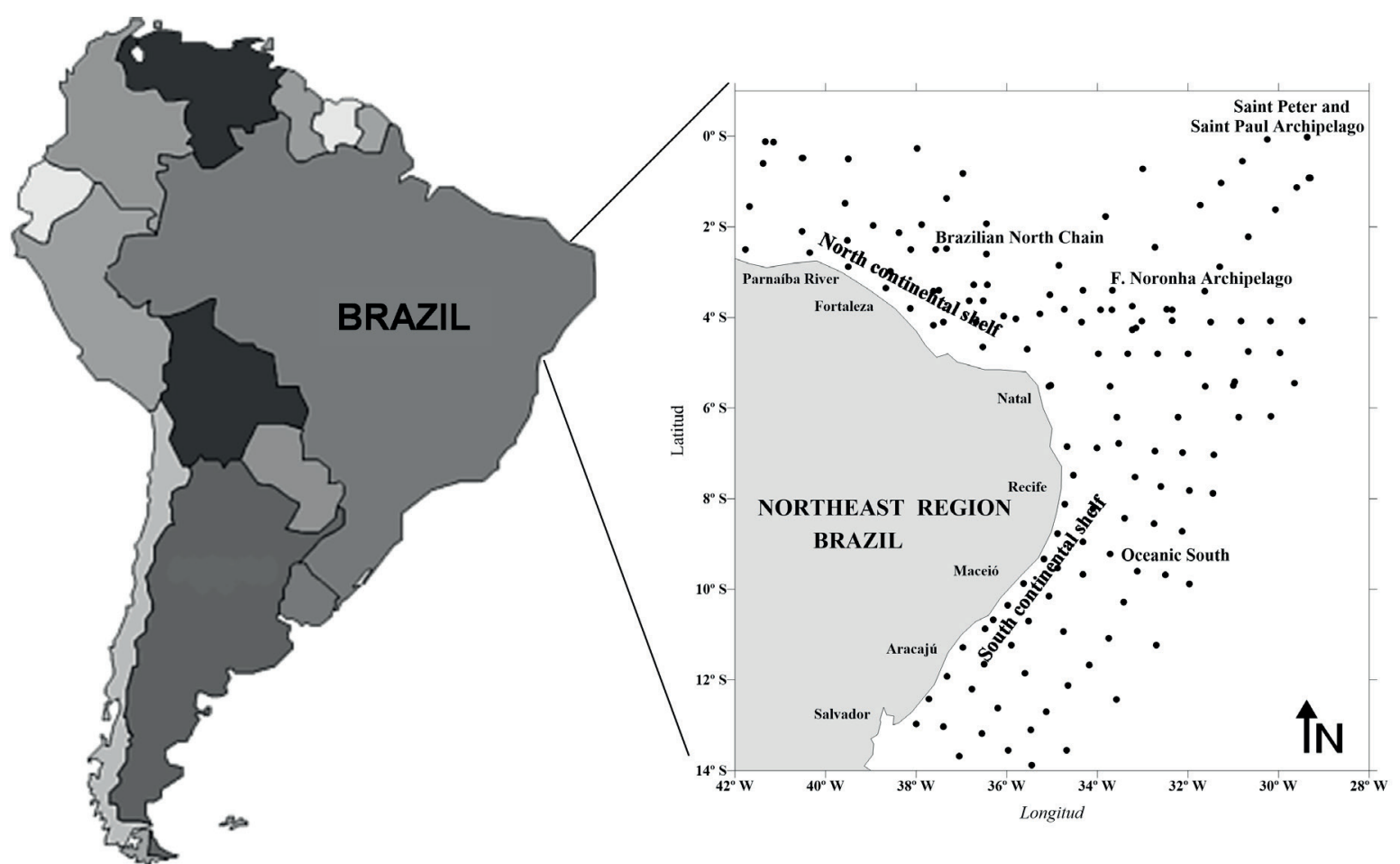

Figure 1 - Study area, showing the sampling stations in the west tropical Atlantic Ocean.

Software Inc. (Keekler 1995). All surface salinity, temperature and phytoplanktonic biomass maps refer to data collected at $10 \mathrm{~m}$ depth.

Canonical correspondence analysis (CCA), which incorporates environmental variables by aligning species and station data along environmental gradients, was used to explore the relationship between fish larvae and oceanographic variables (temperature, salinity, phytoplankton biomass, zooplankton biomass and station depth).

Thirty-six of the 562 original collections were excluded based on the absence of fish larvae, leaving 526 collections for the CCA. Only eight dominant taxa were retained in the CCA. The large number of collections ensured a robust result.

For the CCA, 1946 cases of species abundances were entered as $\log$ transformed densities, i.e $\ln$ (no. $\mathrm{x} 100 \mathrm{~m}^{-3}$ ), representing all occurrences of the 8 taxa from the 526 samples. The 5 environmental variables were all entered into the CCA in their standardized form (i.e. adjusted for a mean of 0 and SD of 1). Monte Carlo test was employed to determine the statistical significance for the first CCA axes and all CCA axes.

The species-environment correlation is a measure of the strength of the relation between the species data and the environmental data for each CCA dimension (ter Braak and Smilauer 2002). Canonical correspondence analysis (CCA), a unimodal for non-linear multivariate gradient analysis, was employed for this study using the CANOCO program.

\section{RESULTS}

\section{OCEANOGRAPHIC CONDITIONS}

The T/S-values of the areas are similar, indicating the same water mass composition; therefore, the data in Figure 2 are treated together for the whole area. A T/S-diagram is given for the upper $200 \mathrm{~m}$ water layer, which corresponds to the maximum depth of the plankton hauls. It shows warm, saline Tropical Water (TW) down to $100 \mathrm{~m}$ and 
below this, a zone influenced by this South Atlantic Central Water (SACW). The TW is characterized by temperatures $>20^{\circ} \mathrm{C}$ and salinities $>36$. The SACW is characterized by temperatures between 5 and $20^{\circ} \mathrm{C}$ and salinities between 34.5 and 36 (Figure 2).

Higher temperatures were found in the continental shelf between Natal and Maceio during Period $2\left(\mathrm{~T}>29^{\circ} \mathrm{C}\right)$ and in the North continental shelf during Period $3\left(\mathrm{~T}>28{ }^{\circ} \mathrm{C}\right)$. A portion of the South continental shelf between Recife and Salvador is occupied by a pool of almost isothermal and relatively cooler water $(25<\mathrm{T}<26$ $\left.{ }^{\circ} \mathrm{C}\right)$ during Period 3. In the Saint Peter and Saint Paul Archipelago, a relatively cold water core (26 ${ }^{\circ} \mathrm{C}<\mathrm{T}<26.6{ }^{\circ} \mathrm{C}$ ) was observed on the upper layers between 10 and $25 \mathrm{~m}$ depth during Period 2 .

A significant correlation is observed between the horizontal distribution of salinity and temperature, during Periods 1,3 and 4 . In general, the local temperature minima $\left(\mathrm{T}<26{ }^{\circ} \mathrm{C}\right)$ over the South continental shelf were associated with salinity water varying between 36.6 and 37.2. The surface salinity did not show any significant variation down to $25 \mathrm{~m}$ depth.

PHYTOPLANKTON BIOMASS

Phytoplankton biomass as chlorophyll $a$ showed a gradient decreasing gradually from North area to the South area. Higher chlorophyll $a$ values were observed near the Saint Peter and Saint Paul
Archipelago $(3.8 \mu / \mathrm{L})$ during Period 2, $(5.41 \mu / \mathrm{L})$ during Period 4 and in the continental shelf area between Recife and Parnaiba river $(4.9 \mu / \mathrm{L})$ during Period 3 (Figure 3).

\section{ZOOPLANKTON BIOMASS}

Differences between the North area (seamounts and islands) and the South area (oceanic) became clearly evident in zooplankton biomass (Figure 4). The total biomass of the $500 \mu \mathrm{m}$ catches varied between 0.1 and $10.5 \mathrm{~g} .100 \mathrm{~m}^{-3}$, with an average of $0.97 \mathrm{~g} .100 \mathrm{~m}^{-3}$. Higher biomass values were found in the Saint Peter and Saint Paul Archipelago, during Periods 2 and 3 and in the Brazilian North Chain, Fernando de Noronha Archipelago and South continental shelf, during Period 4. Biomass maxima corresponded to the Brazilian North Chain during Period 2 (Figure 4).

\section{LARVAL FISH COMPOSITION AND ABUNDANCE}

From the 19,425 larvae collected during Period 1 (2,969 larvae), Period 2 (5,941 larvae), Period 3 (4,697 larvae) and Period 4 (5,818 larvae), 100 taxa (64 families, 19 orders and 17 suborders) were identified.

\section{Species list}

Phylum Chordata

Other Elopiformes

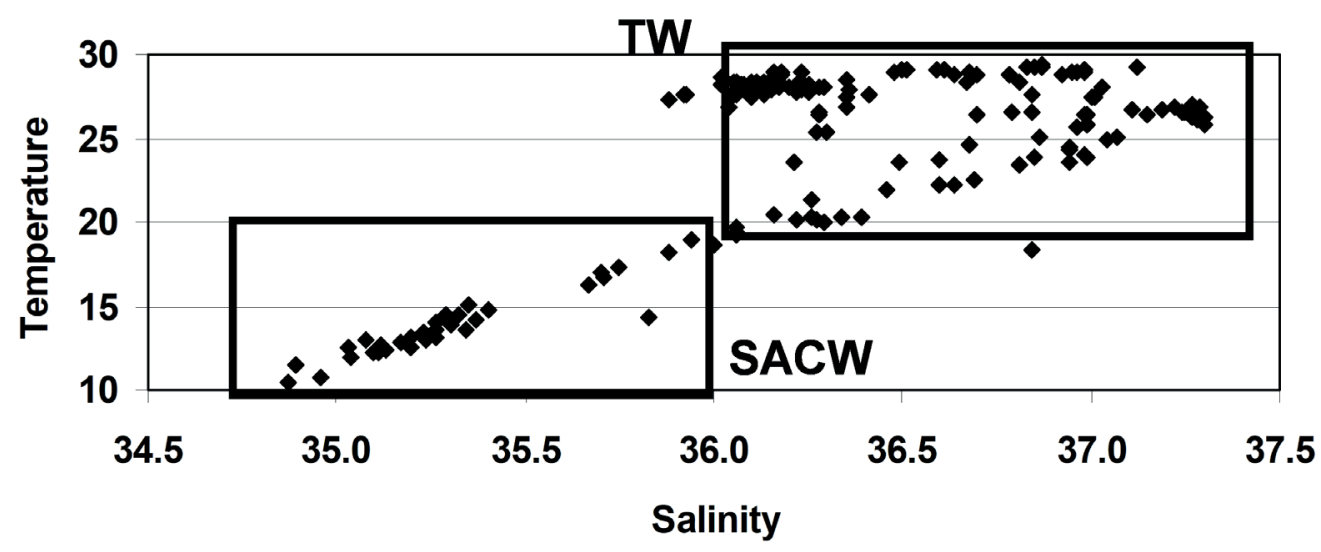

Figure 2 - Temperature-salinity diagrams. 


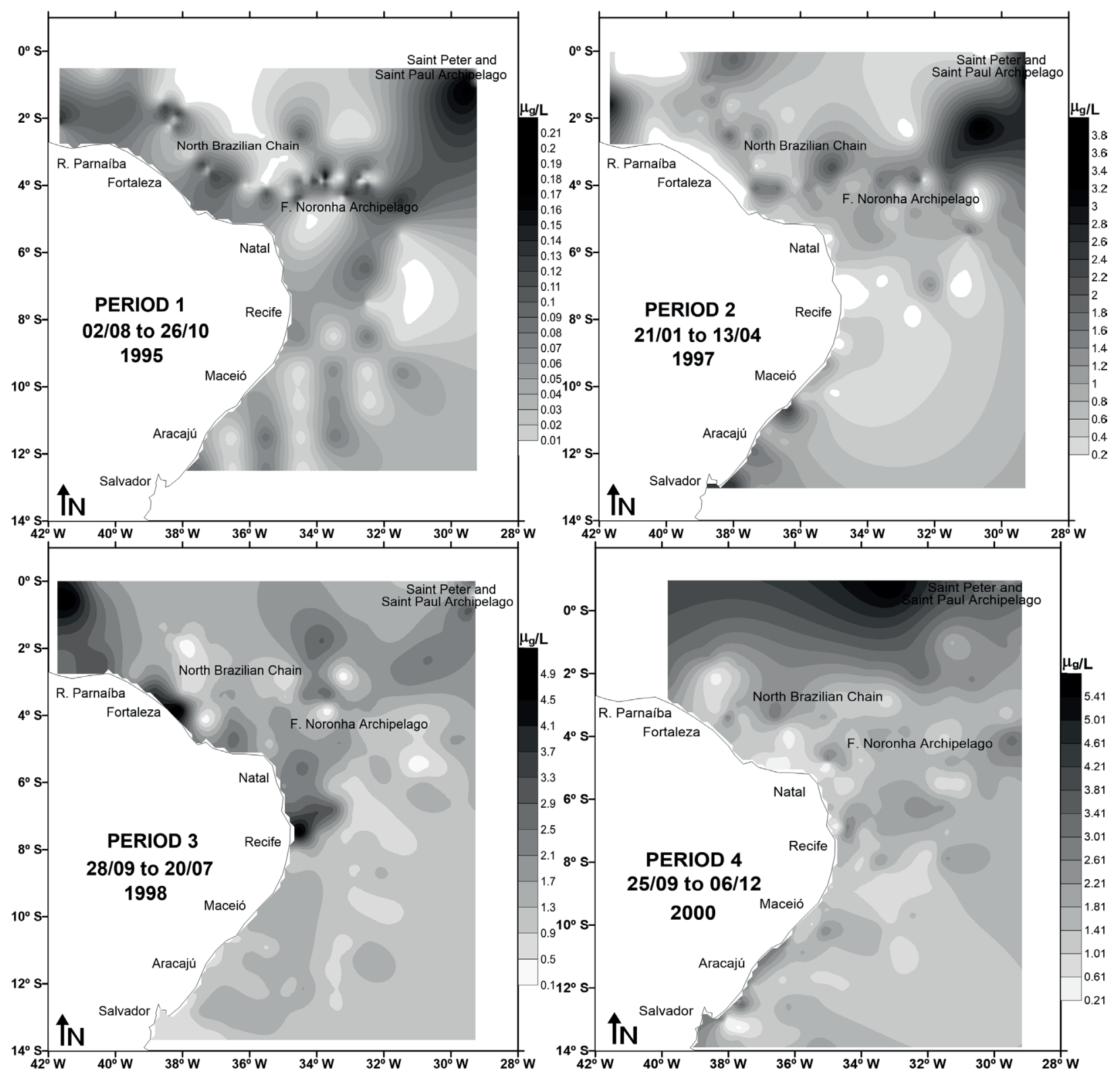

Figure 3 - Horizontal distribution of Chlorophyll $a(\mathrm{mg} \mathrm{L}-1)$ at the $1 \%$ in the west tropical Atlantic Ocean.

Family Elopidae

$$
\text { Elops sp. }
$$

Other Albuliformes

Family Albulidae

$$
\text { Albula sp. }
$$

Other Anguilliformes

Family Ophichthidae

Myrichthys sp.

Ophichthus sp.
Other Clupeiformes

Family Engraulididae

Lycengraulis grossidens (Spix \& Agassiz, 1829)

Family Clupeidae

Other Osmeriformes

Family Osmeridae

Other Stomiiformes

Family Gonostomatidae 


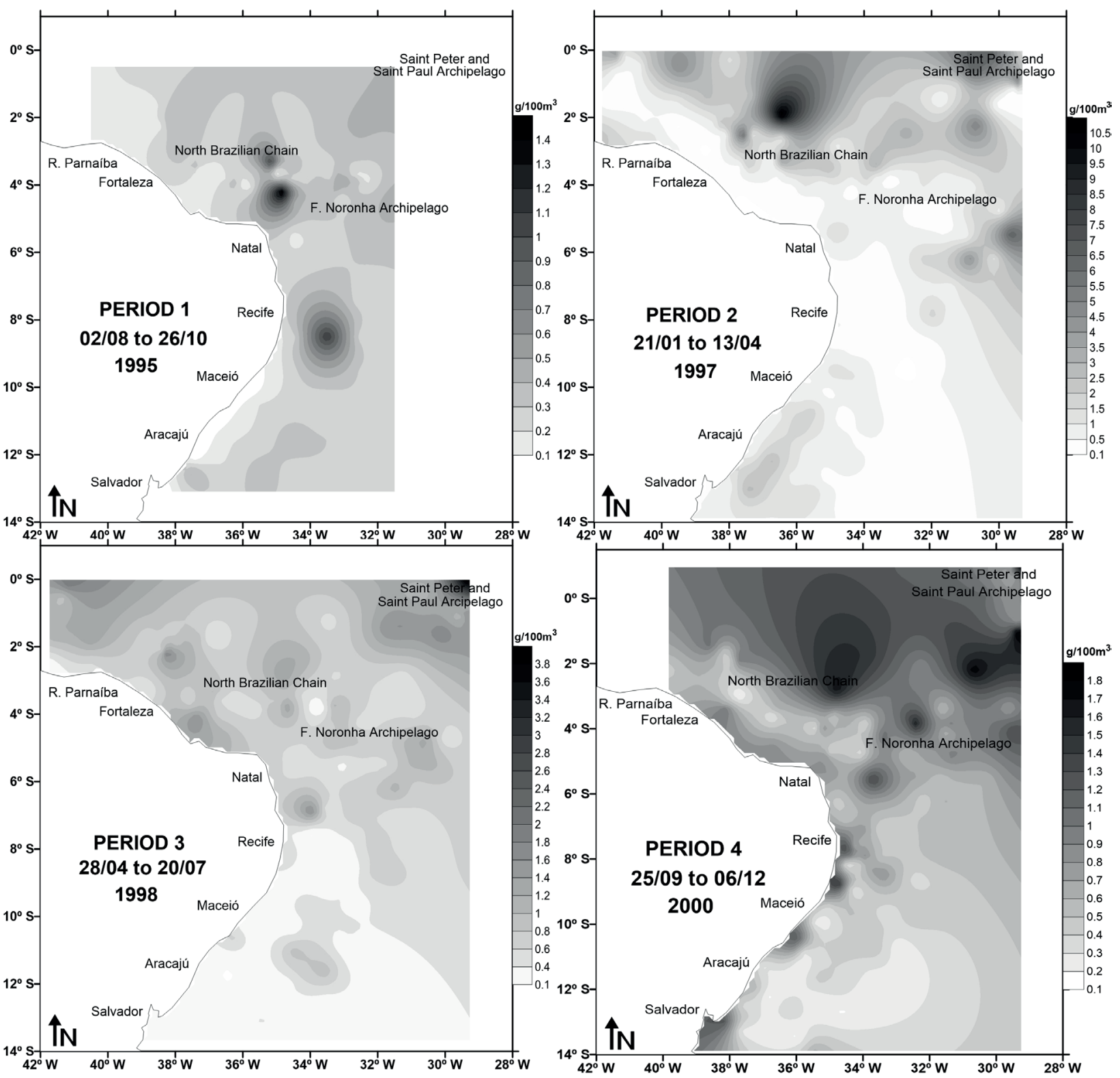

Figure 4 - Zooplankton biomass $\left(\mathrm{g} / 100 \mathrm{~m}^{3}\right)$ in the west tropical Atlantic Ocean.

Cyclothone sp.

Family Phosichthyidae

Vinciguerria sp.

Family Stomiidae

Stomias sp.

Family Melanostomiidae

Family Idiacanthidae

Idiacanthus $\boldsymbol{s p}$

Other Aulopiformes

Family Scopelarchidae
Family Paralepididae

Lestidium sp.

Family Evermannellidae

Evermannela sp.

Other Myctophiformes

Family Neoscopelidae

Family Myctophidae

Diogenichthys atlanticus (Tåning, 1928)

Hygophum spp.

Myctophum spp. 
Diaphus spp.

Lampadena sp.

Notoscopelus sp

Other Ophidiiformes

Family Ophidiidae

Family Carapidae

Other Gadiiformes

Family Macrouridae

Family Bregmacerotidae

Bregmaceros cantori Milliken \&

Houde, 1984

Family Gadidae

Other Lophiformes

Family Ceratiidae

Other Mugiliformes

Family Mugilidae

Mugil sp

Other Beloniformes

Family Exocoetidae

Cypselurus cyanopterus

(Valenciennes, 1846)

Hirundichthys affinis (Gunther, 1866)

Family Hemiramphidae

Hemiramphus brasiliensis (Linnaeus, 1758)

Hyporhamphus unifasciatus (Ranzani, 1841)

Other Beryciformes

Family Holocentridae

Holocentrus sp.

Other Gasterosteiformes

Family Syngnathidae

Hippocampus reidi Ginsburg, 1933

Family Fistularidae

Fistularia petimba Lacepède, 1803

Other Scorpaeniformes

Family Dactylopteridae

Dactylopterus volitans (Linnaeus, 1758)

Family Scorpaenidae

Family Triglidae

Family Cottidae
Other Perciformes

Family Serranidae

Epinephelus sp.

Family Priacanthidae

Priacanthus sp.

Family Apogonidae

Family Echeneidae

Family Carangidae

Carangoides spp.

Caranx spp.

Chloroscombrus chrysurus (Linnaeus, 1766)

Decapterus punctatus (Cuvier, 1829)

Elagatis bipinnulatus (Quoi \& Gaimard, 1824)

Selene setapinnis (Mitchill, 1815)

Selene vomer (Linnaeus, 1758)

Trachurus lathami Nichols, 1920

Family Bramidae

Family Lutjanidae

Lutjanus sp.

Family Gerreidae

Family Haemulidae

Family Sparidae

Family Pomacanthidae

Family Pomacentridae

Family Labridae

Family Scaridae

Cryptotomus roseus Cope, 1871

Sparisoma sp.

Family Blenniidae

Family Callionymidae

Family Gobiidae

Family Acanthuridae

Acanthurus spp.

Family Scombrolabracidae

Scombrolabrax heterolepis Roule, 1921

Family Sphyraenidae

Sphyraena spp.

Family Gempylidae

Family Scombridae 
Acanthocybium solandri (Cuvier, 1831)

Euthynnus aletteratus (Rafinesque, 1810)

Katsuwonus pelamis (Linnaeus, 1758)

Scomberomorus sp.

Thunnus spp.

Family Nomeidae

Other Pleuronectiformes

Family Bothidae

Bothus ocellatus (Agassiz,1831)

Engyophrys senta Ginsburg, 1933

Family Paralichthydae

Citharichthys cf. spilopterus Gunther,

1862

Citharichthys sp.

Syacium papillosum (Linnaeus, 1758)

Family Cynoglossidae

Symphurus sp.

Other Tetraodontiformes

Family Balistidae

Balistes capriscus Gmelin, 1788

Family Monacanthidae

Stephanolepis hispidus (Linnaeus, 1766)

Family Ostracidae

Lactophrys trigonus (Linnaeus, 1758)

Family Tetraodontidae

Sphoeroides sp 1

Sphoeroides sp2

Family Diodontidae

Diodon hystrix Linnaeus, 1758

Family Molidae

Ranzania laevis (Pennant, 1776)

The abundance of the family groups of fish larvae is given in Table I. During the four periods, $80 \%$ of the total larvae taken represented eight characteristics families in increasing order of abundance: Scombridae (0.6\%), Carangidae (1.6\%), Paralepididae (2.7\%), Bothidae (3.3\%), Gonostomatidae (5.6\%), Scaridae (7.5\%),
Gobiidae (21\%) and Myctophidae (37.7\%). Five families (Gadidae, Macrouridae, Monacantidae, Evermannelidae and Scombrolabracidae) were collected only in Period 4. The total number of larvae collected during Period 1 was less as that of the other three cruises. In this Period was observed the lowest taxon number.

In relation to habitat of adult fish groups, four dominant fish groups were recognized in the tropical Atlantic Ocean: epipelagic fish, mesopelagic fish, demersal fish and coral-reef-associated fish. Levels of abundance of mesopelagic fish larvae (Myctophidae and Gonostomatidae) were highest during Period 2 and Period 4. For other family (Paralepididae) levels of abundance were highest for Period 3, decreased in Period 2 and Period 4, and were at a minimum during Period 1. Abundance of Gobiidae (coral-reef-associated fish) was at a peak in Period 2, followed by Period 4 and Period 1. Bothidae family (Demersal fish larvae) were most abundant during Period 2 and Period 3. For the Scaridae family, a peak in larval abundance was observed during Period 3. Levels of abundance of families of epipelagic fish larvae (Caragidae and Scombridae) were very low during investigated periods.

\section{SPATIAL AND TEMPORAL DISTRIBUTION PATTERNS OF FISH LARVAE}

Fish larvae showed a rather heterogeneous distribution with density at each station ranging from 0.5 larvae per $100 \mathrm{~m}^{3}$ to 2000 larvae per $100 \mathrm{~m}^{3}$. A general trend was observed towards lower density at oceanic stations, with abundance generally not more than 20 larvae per $100 \mathrm{~m}^{3}$. Higher densities were found at stations located close to the Saint Peter and Saint Paul Archipelago (30 to 350 larvae per $100 \mathrm{~m}^{3}$ ), Brazilian North Chain (40 to 750 larvae per $100 \mathrm{~m}^{3}$ ) and Fernando de Noronha Archipelago (40 to 550 larvae per $100 \mathrm{~m}^{3}$ ) during Periods 1, 2 and 3. Some stations located in the South continental shelf showed densities ranging 
TABLE I

Family groups represented in ichtyoplankton samples collected in the west tropical Atlantic Ocean. Abundance is a sum of larvae from all positive stations and \% is a percentage of total abundance.

\begin{tabular}{|c|c|c|c|c|c|c|c|c|}
\hline & Period 1 & & Period 2 & & Period 3 & & Period 4 & \\
\hline Taxon & Abundance & $\%$ & Abundance & $\%$ & Abundance & $\%$ & Abundance & $\%$ \\
\hline ANGUILLIFORMES & 30 & 1.01 & 109 & 1.83 & 93 & 1.98 & 75 & 1.34 \\
\hline Clupeidae & 0 & 0.00 & 6 & 0.10 & 16 & 0.34 & 2 & 0.04 \\
\hline Engraulidae & 2 & 0.07 & 21 & 0.35 & 8 & 0.17 & 1 & 0.02 \\
\hline Osmeridae & 0 & 0.00 & 7 & 0.12 & 7 & 0.15 & 8 & 0.14 \\
\hline STOMIIFORMES & 0 & 0.00 & 0 & 0.00 & 3 & 0.06 & 0 & 0.00 \\
\hline Gonostomatidae & 99 & 3.33 & 438 & 7.37 & 244 & 5.19 & 300 & 5.36 \\
\hline Photichthyidae & 7 & 0.24 & 16 & 0.27 & 4 & 0.09 & 122 & 2.18 \\
\hline Stomiidae & 1 & 0.03 & 11 & 0.19 & 22 & 0.47 & 11 & 0.20 \\
\hline Melanostomiidae & 22 & 0.74 & 19 & 0.32 & 19 & 0.40 & 37 & 0.66 \\
\hline Idiacanthidae & 0 & 0.00 & 2 & 0.03 & 0 & 0.00 & 4 & 0.07 \\
\hline Scopelarchidae & 0 & 0.00 & 14 & 0.24 & 48 & 1.02 & 23 & 0.41 \\
\hline Paralepididae & 56 & 1.89 & 94 & 1.58 & 236 & 5.02 & 145 & 2.59 \\
\hline Evermannellidae & 0 & 0.00 & 0 & 0.00 & 0 & 0.00 & 11 & 0.20 \\
\hline Neoscopelidae & 0 & 0.00 & 0 & 0.00 & 11 & 0.23 & 1 & 0.02 \\
\hline Myctophidae & 631 & 21.25 & 2205 & 37.11 & 1866 & 39.73 & 2619 & 46.82 \\
\hline Gadidae & 0 & 0.00 & 0 & 0.00 & 0 & 0.00 & 3 & 0.05 \\
\hline Macrouridae & 0 & 0.00 & 0 & 0.00 & 0 & 0.00 & 17 & 0.30 \\
\hline Bregmacerotidae & 10 & 0.34 & 14 & 0.24 & 26 & 0.55 & 30 & 0.54 \\
\hline Ophidiidae & 2 & 0.07 & 8 & 0.13 & 21 & 0.45 & 27 & 0.48 \\
\hline Carapidae & 0 & 0.00 & 0 & 0.00 & 2 & 0.04 & 0 & 0.00 \\
\hline LOPHIFORMES & 0 & 0.00 & 0 & 0.00 & 2 & 0.04 & 0 & 0.00 \\
\hline Ceratioidei & 9 & 0.30 & 10 & 0.17 & 14 & 0.30 & 16 & 0.29 \\
\hline Exocoetidae & 3 & 0.10 & 6 & 0.10 & 6 & 0.13 & 8 & 0.14 \\
\hline Hemiramphidae & 0 & 0.00 & 5 & 0.08 & 9 & 0.19 & 13 & 0.23 \\
\hline Holocentridae & 7 & 0.24 & 7 & 0.12 & 5 & 0.11 & 24 & 0.43 \\
\hline Syngnathidae & 3 & 0.10 & 2 & 0.03 & 1 & 0.02 & 4 & 0.07 \\
\hline Fistularidae & 0 & 0.00 & 1 & 0.02 & 1 & 0.02 & 3 & 0.05 \\
\hline Dactylopteridae & 5 & 0.17 & 10 & 0.17 & 0 & 0.00 & 6 & 0.11 \\
\hline Scorpaenidae & 0 & 0.00 & 0 & 0.00 & 1 & 0.02 & 2 & 0.04 \\
\hline Triglidae & 0 & 0.00 & 1 & 0.02 & 0 & 0.00 & 0 & 0.00 \\
\hline Cottidae & 0 & 0.00 & 6 & 0.10 & 0 & 0.00 & 0 & 0.00 \\
\hline PERCIFORMES & 7 & 0.24 & 2 & 0.03 & 25 & 0.53 & 28 & 0.50 \\
\hline Percoidei & 1 & 0.03 & 10 & 0.17 & 11 & 0.23 & 26 & 0.46 \\
\hline Echeneidae & 0 & 0.00 & 0 & 0.00 & 0 & 0.00 & 0 & 0.00 \\
\hline Serranidae & 11 & 0.37 & 36 & 0.61 & 9 & 0.19 & 50 & 0.89 \\
\hline Priacanthidae & 6 & 0.20 & 14 & 0.24 & 15 & 0.32 & 11 & 0.20 \\
\hline Apogonidae & 5 & 0.17 & 52 & 0.88 & 1 & 0.02 & 25 & 0.45 \\
\hline Carangidae & 12 & 0.40 & 90 & 1.51 & 146 & 3.11 & 65 & 1.16 \\
\hline Bramidae & 10 & 0.34 & 21 & 0.35 & 20 & 0.43 & 30 & 0.54 \\
\hline Lutjanidae & 0 & 0.00 & 3 & 0.05 & 23 & 0.49 & 20 & 0.36 \\
\hline Gerreidae & 1 & 0.03 & 20 & 0.34 & 16 & 0.34 & 1 & 0.02 \\
\hline Cotiidae & 0 & 0.00 & 0 & 0.00 & 0 & 0.00 & 0 & 0.00 \\
\hline Monacantidae & 0 & 0.00 & 0 & 0.00 & 0 & 0.00 & 5 & 0.09 \\
\hline
\end{tabular}


TABLE I (continuation)

\begin{tabular}{|c|c|c|c|c|c|c|c|c|}
\hline & Period 1 & & Period 2 & & Period 3 & & Period 4 & \\
\hline Taxon & Abundance & $\%$ & Abundance & $\%$ & Abundance & $\%$ & Abundance & $\%$ \\
\hline Haemulidae & 2 & 0.07 & 74 & 1.25 & 158 & 3.36 & 85 & 1.52 \\
\hline Sparidae & 0 & 0.00 & 1 & 0.02 & 1 & 0.02 & 2 & 0.04 \\
\hline Sciaenidae & 0 & 0.00 & 0 & 0.00 & 1 & 0.02 & 0 & 0.00 \\
\hline Pomacanthidae & 0 & 0.00 & 4 & 0.07 & 7 & 0.15 & 6 & 0.11 \\
\hline Pomacentridae & 0 & 0.00 & 20 & 0.34 & 2 & 0.04 & 6 & 0.11 \\
\hline Mugilidae & 0 & 0.00 & 2 & 0.03 & 2 & 0.04 & 0 & 0.00 \\
\hline Sphyraenidae & 0 & 0.00 & 3 & 0.05 & 7 & 0.15 & 0 & 0.00 \\
\hline Labridae & 18 & 0.61 & 71 & 1.20 & 33 & 0.70 & 81 & 1.45 \\
\hline Scaridae & 385 & 12.97 & 299 & 5.03 & 588 & 12.52 & 181 & 3.24 \\
\hline Blennioidei & 0 & 0.00 & 19 & 0.32 & 0 & 0.00 & 5 & 0.09 \\
\hline Blenniidae & 0 & 0.00 & 10 & 0.17 & 0 & 0.00 & 3 & 0.05 \\
\hline Callionymidae & 15 & 0.51 & 64 & 1.08 & 68 & 1.45 & 103 & 1.84 \\
\hline Gobiidae & 1017 & 34.25 & 1582 & 26.63 & 423 & 9.01 & 1059 & 18.93 \\
\hline Acanthuridae & 44 & 1.48 & 10 & 0.17 & 9 & 0.19 & 13 & 0.23 \\
\hline Scombrolabracidae & 5 & 0.17 & 0 & 0.00 & 0 & 0.00 & 0 & 0.00 \\
\hline Gempylidae & 11 & 0.37 & 16 & 0.27 & 34 & 0.72 & 32 & 0.57 \\
\hline Scombridae & 25 & 0.84 & 32 & 0.54 & 71 & 1.51 & 27 & 0.48 \\
\hline Scombrolabracide & 0 & 0.00 & 0 & 0.00 & 0 & 0.00 & 15 & 0.27 \\
\hline Nomeidae & 13 & 0.44 & 49 & 0.82 & 75 & 1.60 & 16 & 0.29 \\
\hline PLEURONECTIFORMES & 1 & 0.03 & 0 & 0.00 & 5 & 0.11 & 0 & 0.00 \\
\hline Bothidae & 101 & 3.40 & 297 & 5.00 & 181 & 3.85 & 68 & 1.22 \\
\hline Paralictidae & 10 & 0.34 & 21 & 0.35 & 0 & 0.00 & 56 & 1.00 \\
\hline Cynoglossidae & 0 & 0.00 & 4 & 0.07 & 3 & 0.06 & 0 & 0.00 \\
\hline Balistidae & 4 & 0.13 & 4 & 0.07 & 7 & 0.15 & 0 & 0.00 \\
\hline Monacanthidae & 0 & 0.00 & 5 & 0.08 & 0 & 0.00 & 0 & 0.00 \\
\hline Ostracidae & 0 & 0.00 & 0 & 0.00 & 7 & 0.15 & 0 & 0.00 \\
\hline Tetraodontidae & 5 & 0.17 & 8 & 0.13 & 6 & 0.13 & 10 & 0.18 \\
\hline Diodontidae & 0 & 0.00 & 6 & 0.10 & 12 & 0.26 & 3 & 0.05 \\
\hline Molidae & 0 & 0.00 & 2 & 0.03 & 0 & 0.00 & 1 & 0.02 \\
\hline Not identified & 378 & 11.35 & 76 & 1.28 & 66 & 1.41 & 40 & 0.72 \\
\hline Total & 2969 & 100.00 & 5941 & 100.00 & 4697 & 100.00 & 5594 & 100.00 \\
\hline No. of taxa & 38 & & 56 & & 55 & & 56 & \\
\hline
\end{tabular}

from 50 to 150 larvae per $100 \mathrm{~m}^{3}$, during Periods 2 and 4.

Distribution patterns of families among each of the periods are shown in Figures 5 and 6. During Period 3 the highest densities of Brothidae larvae were found at ocean area between F. Noronha Archipelago and Saint Peter and Saint Paul Archipelago, but the Brazilian North Chain stations also showed relatively high density during Period
2 (Figure 5). Carangidae larvae were collected more frequently near the coast. The stations with the highest densities of Carangidae larvae during Periods 2 and 3 were found along the shelf break (Figure 5). Gobiidae larvae during Period 1 were concentrated over the Brazilian North Chain and F. Noronha Archipelago and only a small number of them were collected at open ocean stations (Figure 5). Larvae of Gonostomatidae were found 


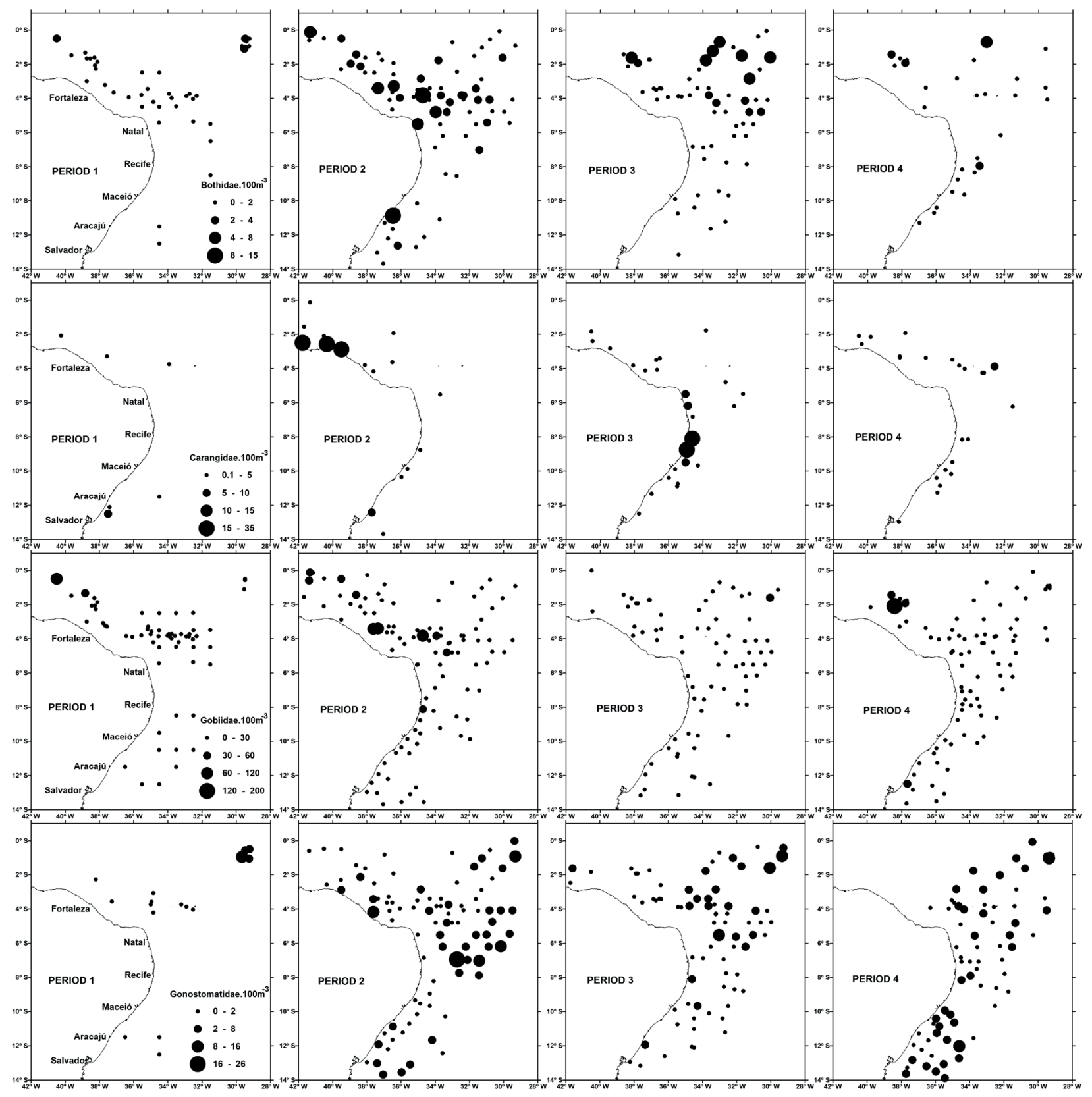

Figure 5 - Distribution and density (larvae. $100 \mathrm{~m}^{-3}$ ) of the fish larvae families (Bothidae, Carangidae, Gobiidae and Gonostomatidae) in the west tropical Atlantic Ocean.

predominantly at open ocean stations during Periods 2, 3 and 4 and some at the continental margin (Figure 5). Myctophidae larvae were collected at open ocean stations with higher density over the Brazilian North Chain and F. Noronha Archipelago during Period 3 and Period 4, but also were collected at coastal stations with higher density between Natal and Salvador on Period 2 and Period 4 (Figure 6). Paralepididae larvae were collected at open ocean stations during all four periods, with higher density in the adjacent area to Saint Peter and Saint Paul Archipelago during Period 3 (Figure 6). The distribution patterns of the larvae Scaridae were similar during all four 


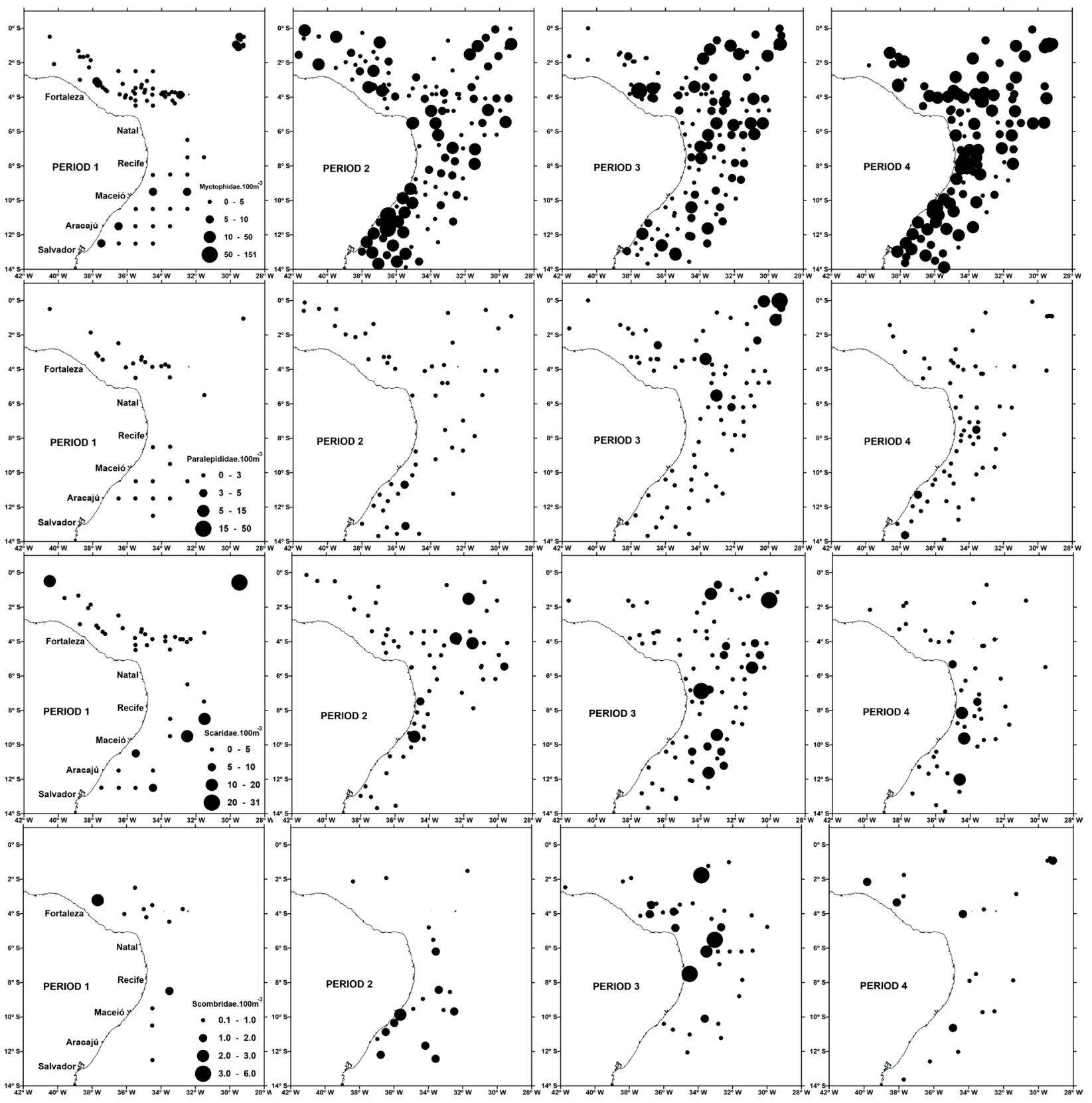

Figure 6 - Distribution and density (larvae. $100 \mathrm{~m}^{-3}$ ) of the fish larvae families (Myctophidae, Paralepididae, Scaridae and Scombridae) in the west tropical Atlantic Ocean.

periods, with higher density at open ocean stations

(Figure 6). Most of the Scombridae larvae were

collected at coastal stations between Maceió and

Aracajú during Period 2 and at open ocean stations during Period 3 (Figure 6).
CORRELATIONS BETWEEN ICHTHYOPLANKTON AND OCEANOGRAPHIC FACTORS

The CCA used environmental information to constrain a reciprocal averaging ordination between taxa and respective samples. Eigenvalues, measures of importance for CCA axes that may vary between zero and one, ranged from 0.087 for CCA 4 to 
TABLE II

Result from canonical correspondence analysis (CCA) of 1946 cases of family occurrence in 526 collections from west tropical Atlantic Ocean.

\begin{tabular}{cccccc}
\hline Axes & $\mathbf{1}$ & $\mathbf{2}$ & $\mathbf{3}$ & $\mathbf{4}$ & Total Inertia \\
\hline Eigenvalues: & 0.651 & 0.453 & 0.139 & 0.087 & 3.197 \\
Species-environment correlations: & 0.785 & 0.629 & 0.544 & 0.493 & \\
Cumulative percentage variance & & & & 30.4 \\
$\quad$ of species data: & 15.5 & 19.2 & 19.9 & 98.9 & 3.197 \\
of species-environment relation: & 51.9 & 87.4 & 94.5 & & 1.33 \\
$\quad$ Sum of all eigenvalues: & & & & & \\
Sum of all canonical eigenvalues: & & & & & \\
\hline
\end{tabular}

0.651 for CCA 1 (Table II). The eigenvalues were moderately high for the first two axes, whereas CCA axes 3 and 4 were relatively low (i.e. $<0.2$ ). Species-environment correlations were high for all four CCA axes, ranging from 0.785 for CCA 1 to 0.493 for CCA 4 .

The combined sum of canonical eigenvalues (1.33) was equal $41 \%$ of that for the unconstrained eigenvalues (3.197), showing the effect of building environmental relationships into the CCA model. The low weighted correlation coefficients of the environmental variables indicated that there were not collinear variables (Table III). This result is important because multicollinear variables must be deleting from the analysis.

The plot of CCA species scores illustrates their dispersion pattern and the plot of oceanographic variables vectors illustrates the directions and strengths of environmental relationships within the first two dimensions of the CCA ordination.

Environmental variables correlated most strongly with CCA 1 included Depth. Another suite of environmental variables correlated best with CCA 2, including Temperature, Salinity, Phytoplankton biomass and Zooplankton biomass (Figure 7). Thus, families with low values on CCA 2 occurred mostly at high salinity and temperature stations, whereas families with high values on CCA 2 occurred mostly at high Phytoplankton biomass and Zooplankton biomass stations. The families that had high values on CCA 1 occurred in greater depths.

Distinctive patterns of dispersion in space occurred for the various ecological groups with respect to the important environmental variable. Bothidae and Gobiidae were positively correlated with second CCA axes, appearing mostly at high phytoplankton biomass and zooplankton biomass. Scaridae, Scombridae and Gonostomatidae were positively correlated with first CCA axes, occurring mostly at deep offshore stations. Carangidae was negatively correlated with first and second CCA axes, predominantly occurring at low phytoplankton biomass and zooplankton biomass and at inshore stations. Myctophidae and Paralepididae were negatively correlated with second CCA axes, predominantly occurring at higher salinities and water temperature (Figure 7).

\section{DISCUSSION}

According to temperature and salinity results, the study area presented typical characteristics of tropical regions, with high salinity and temperature, low thermal oscillation. Consequently, this area is known to be oligotrophic with a low concentration of nitrates, chlorophyll- $a$ biomass, and primary production (Queiroz et al. 2015, Souza et al. 2013, Ekau and Knoppers 1999).

Such characteristics may be explained by the existence of a warm surface layer above a colder and 
TABLE III

Weighted correlation matrix from CCA.

\begin{tabular}{|c|c|c|c|c|c|c|}
\hline Longitude & 1.0000 & & & & & \\
\hline Latitude & 0.1484 & 1.0000 & & & & \\
\hline Station Depth & 0.4239 & -0.0334 & 1.0000 & & & \\
\hline Temperature & -0.0461 & -0.0136 & -0.0334 & 1.0000 & & \\
\hline Salinity & -0.1670 & -0.3340 & -0.1127 & -0.0430 & 1.0000 & \\
\hline \multirow[t]{2}{*}{ Secondary Biomass } & 0.0286 & 0.2898 & 0.1005 & -0.0120 & -0.1424 & 1.0000 \\
\hline & Longitude & Latitude & Station Depth & Temperature & Salinity & Secondary Biomass \\
\hline
\end{tabular}

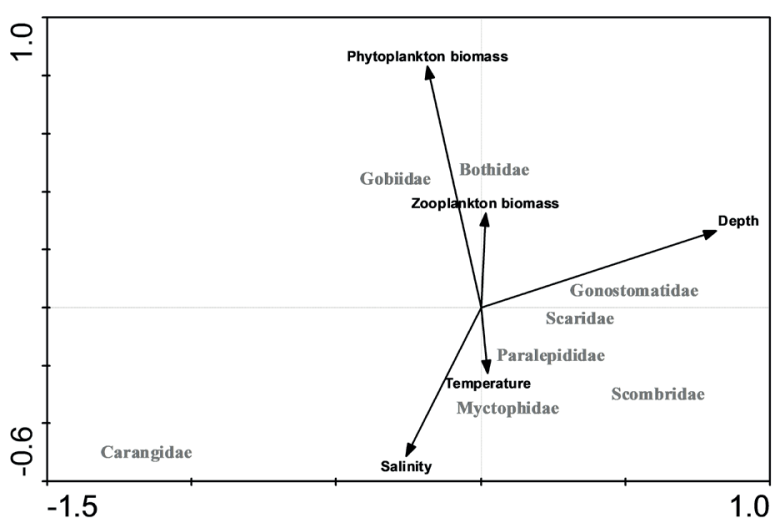

Figure 7 - Biplot of the species scores and important environmental correlation vectors in the first two canonical correspondence analysis dimensions.

denser sub-surface layer, which creates a permanent thermocline. This tends to inhibit the upward flow nutrient of rich deeper layers, restricting primary production in surface waters (Travasso et al. 1999).

The biological parameters showed a remarkable spatial variability for tropical oceanic regions. A gradient of phytoplankton biomass, zooplankton biomass and fish larvae density were observed in all studied periods, with lower concentrations in the South area (oceanic) and higher concentrations in the North area (seamounts and islands). Coastal areas between Rio Grande do Norte and Ceará and between Pernambuco and North Bahia also had high fish larvae density. The role of seamounts and oceanic islands in fishery production is well known to fishermen, since they cause remarkable concentrations of commercially valuable species, as a result of the enhancement process (Fonteneau
1991). Araujo and Cintra (2009) indicate that the interaction of currents with the topography of the St. Peter and St. Paul Archipelago can cause physical processes such as the production of vortices, disturbances of thermohaline structure and possible mechanisms of local upwelling. Queiroz et al. (2015) found variations in depths at which the thermocline starts in the Saint Peter and Saint Paul Archipelago that allows input of the richest water at the base of the photic layer.

The distribution of seamount ichthyoplankton was first considered by Nellen (1974), who reported that the larvae of two 'topographically associated' fish species were more abundant over Great Meteor Seamount than in the surrounding North Atlantic waters. Lessa et al. (1999) observed aggregation of fishes around and close to the Saint Peter and Saint Paul Archipelago, particularly large flying fishes as well as tunas and local fisheries on tunas and bentho-pelagic species, suggest the maintenance of higher biomass in this region in comparison to adjacent waters.

The fish larvae in the west Tropical Atlantic Ocean were produced by a diverse collection of fish family. The high diversity of 72 taxa is characteristic of the tropical marine ecosystem and similar taxonomic richness of larval fish is known from the eastern tropical Pacific (Ahlstrom 1971, 1972) and the Gulf of Mexico (Richards et al. 1993). Many species do not have vertical migratory behavior, thereby changes in species composition at $150 \mathrm{~m}$ would be possible by active vertical 
circulation in the water column above the seamount summit (Diekmann et al. 2006).

The dominant taxonomic groups (family) from the four periods showed a distinct temporal pattern in abundance. The overall larval abundance of Period 2 was the highest. The Myctophidae larvae abundance was highest during Periods 2 and 4 with high water temperature. Myctophid fish in the temperate and subtropical seas are known to spawn mainly from late winter to summer, coinciding with the seasonal peak of zooplankton production in the area (Doyle et al. 1993). Variable patterns have been observed at Southeast Hancock Seamount, where the larvae abundance of two species of the Myctophidae larvae, Maurolicus muelleri and Pseudopentaceros wheeleri varied seasonally, being more abundant over the seamount than the surrounding waters in summer (Boehlert 1988).

Among the Bothidae, the larval abundance of Bothus ocellatus was highest in eriods 2 and 3. Another species (Engyophrys senta) also showed relatively high values in Period 2 and insignificant in other periods. With the Carangidae, the larval abundance of Decapterus punctatus was highest during Periods 1 and 3, while Period 2 was lower abundance. ThelarvalabundanceofChloroscombrus chrysurus was highest during Period 2. Selene setapinnis, Selene vomer and Elagatis bipinnulata were less abundant in all periods. Few studies have reported a high abundance of $S$. setapinnis, ranging from $0.2 \%$ to $2 \%$ of collections in the southern Atlantic off the Brazilian coast (Campos et al. 2010, Souza and Mafalda Jr. 2008). Flores-Coto and Sanchez-Ramirez (1989) found S. setapinnis comprised $6.1 \%$ of collections and were most abundant in warmer months in the southern Gulf of Mexico. This is in contrast with results of other studies in the Gulf of Mexico, which have typically found C. chrysurus to be the dominant species (Ditty et al. 2004, Flores-Coto and SanchezRamirez 1989, Aprieto 1974). Costa et al. (2005) examined carangid distributions in a semi-enclosed bay in southeastern Brazil and found C. chrysurus abundance and biomass was significantly related to decreased salinity and shallow water depths.

A Conceptual model of the fish larvae assemblage in the Brazil tropical oceanic zone is presented in Figure 8. Events such as larval drift, vertical migration and upwelling might be responsible for the formation, maintenance and breakdown of this high standing stock. Topography upwelling causes an increase of nutrient availability in the subsurface waters and increase of phytoplankton growth, the first larval stages might find enough food to develop. Fish tend to spawn on specific sites that are associated with favorable nursery areas (Figure 8).

During vertical migration, larvae of mesopelagic fish are transported by the prevailing current-system during their night-time ascent and the larvae of epipelagic, demersal and coralreef-associated fish drift with the surface current, gradually displacing to form the oceanic assemblage the tropical Atlantic.

Larval fish distribution in the west tropical Atlantic Ocean varied overtime and among sampling locations. Larvae of mesopelagic (Myctophidae, Gonostomatidae and Paralepididae) and coral-reefassociated groups (Scaridae and Gobiidae) were sampled at open ocean stations. In offshore areas, diversity may be increased by mesopelagic and bathypelagic species, which are distributed in the water column according to the abundance of their potential prey (Moser and Smith 1993) and depth of the thermocline (Longhurst 1985). According to Nonaka et al. (2000) and Diekmann et al. (2006), pelagic species belonging to the Myctophidae, Gonostomatidae, Paralepididae, Phosichthyidae and Exocoetidae are dominant in the oceanic assemblage. Gonostomatidae have a circumglobal distribution (Briggs 1960, Fahay 1983) and usually have high species richness in oceanic samples (Moyano et al. 2009, Moyano and Hernández-León 2011). The wide larval distribution, especially 
Gobiidae, might be a consequence of a high larval drift from the coral-reef area where massive spawning occurs (Mafalda Jr. and Rubín 2006).

Larvae of Carangidae (epipelagic) were collected more frequently near the coast. Nonaka et al. (2000) studying larval fish assemblages of the Abrolhos Bank region found a neritic assemblage composed of pelagic fish, such as the Clupeidae, Engraulidae, Carangidae, and Bregmacerotidae. Coastal regions adjacent to estuaries present favourable conditions for the development of fish species that use these areas as nursery and protection for their eggs and larvae.

Studies that interpret ichthyoplankton structure in terms of adult characteristics often find spatially heterogeneous distribution of larvae that are attributable to adult characteristics (Gaughan et al. 1990, Yoklavich et al. 1992). Knowing geographical locations of spawning adults can also help explain spatial heterogeneity in ichthyoplankton structure (Rakocinski et al. 1995).
The commonalities and differences in speciesenvironment relationships were exhibited in the the CCA plots. A gradient in temperature, salinity, phytoplankton biomass, zooplankton biomass and station depth was strongly correlated with changes in ichthyoplankton structure. The CCA plots demonstrated that Myctophidae and Paralepididae responded similarly with increased abundance at high salinities and temperatures. Bothidae and Gobiidae were more abundant at higher phytoplankton biomass and zooplankton biomass. Scaridae, Scombridae and Gonostomatidae displayed similar spatial arrangement in CCA plots, with higher abundances at deep offshore stations. Macedo-Soares et al. (2014) found that water masses were the main components that accounted for the composition of fish larval assemblages along the South Brazil Shelf. It is known that several fish species have their reproductive strategies adjusted for environmental factors such as surface currents. Meteorological and oceanographic conditions influence the feeding of organisms and eggs and

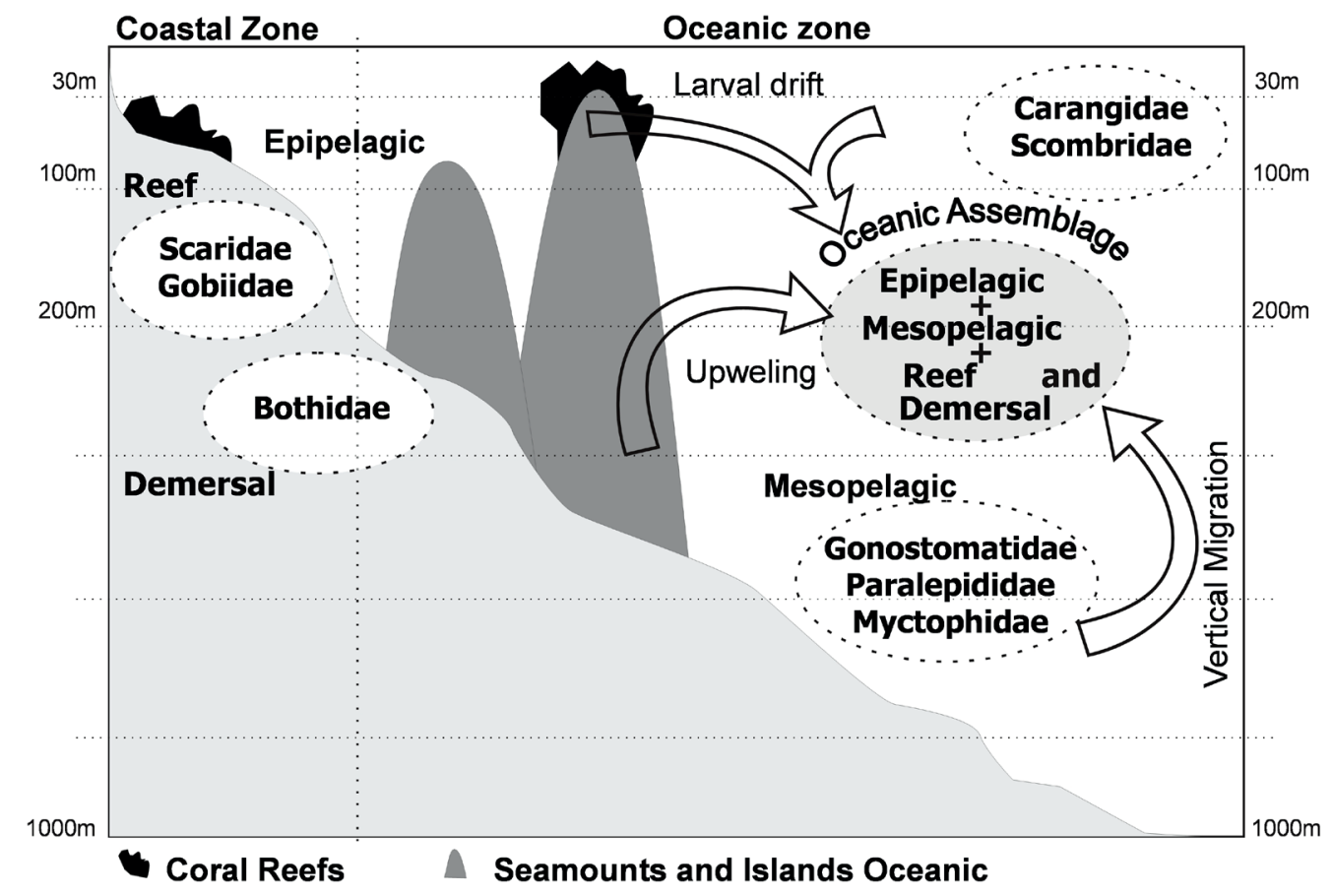

Figure 8 - Conceptual model of the fish larvae assemblage in the west tropical Atlantic Ocean. 
larvae can be transported by currents (Freitas and Muelbert 2004). As a result, the reproductive success of fish is affected resulting in recruitment variability.

In conclusion, our study supports the hypothesis that in the west tropical Atlantic Ocean, temporal and spatial differences in both composition and abundance of ichthyoplankton appeared to be associated with differences in geological and environmental conditions.

\section{ACKNOWLEDGMENTS}

The authors express their thanks to Ministério do Meio Ambiente (MMA), Diretoria de Hidrografia e Navegação (DHN) and ANTARES oceanographical ship, for supporting this study though the program REVIZEE.

\section{REFERENCES}

AHLSTROM EH. 1971. Kinds and abundance of fish larvae in the eastern tropical Pacific, based on collections made on EASTROPAC. Fish Bull 69: 3-77.

AHLSTROM EH. 1972. Kinds and abundance of fish larvae in the eastern tropical Pacific on the second multivessel EASTROPAC survey, and observations on the annual cycle of larval abundance. Fish Bull 70: 1153-1242.

APRIETO VL. 1974. Early development of five carangid fishes of the Gulf of Mexico and the South Atlantic Coast of the United States. Fish Bull 72: 414-443.

ARAUJO M AND CINTRA M. 2009. Modelagem matemática da circulação oceânica na região equatorial. In: Viana DL, Hazin F, Vieira H and Carvalho de Souza MA (Eds), O arquipélago São Pedro e São Paulo: 10 anos de Estação científica. Brasília, DF: SECIRM, p. 106-113.

BOEHLERT GW. 1988. Current-topography interactions at mid-ocean seamounts and the impact on pelagic ecosystems. GeoJournal 16: 45-62.

BRIGGS JC. 1960. Fishes of worldwide (circumtropical) distribution. Copeia 1960: 171-180.

CAMPOS PN, CASTRO MS AND BONECKER ACT. 2010. Occurrence and distribution of Carangidae larvae (Teleostei, Perciformes) from the Southwest Atlantic Ocean, Brazil (12-23ํㅇ). J Appl Ichthyol 26: 920-924.

COSTA MR, ALBIERI RJ AND ARAÚJO FG. 2005. Size distribution of the jack Chloroscombrus chrysurus (Linnaeus) (Actinopterygii, Carangidae) in a tropical bay at Southeastern Brazil. Rev Bras Zool 22: 580-586.
DIEKMANN R, NELLEN W AND PIATKOWSKI U. 2006. A multivariate analysis of larval fish and paralarval cephalopod assemblages at Great Meteor Seamount. Deep Sea Res Part 1 53: 1635-1657.

DITTY JG, SHAW RF AND COPE JS. 2004. Distribution of carangid larvae (Teleostei: Carangidae) and concentrations of zooplankton in the northern Gulf of Mexico, with illustrations of early Hemicaranx amblyrhynchus and Caranx spp. larvae. Mar Biol 145: 1001-1014.

DOYLE MJ, MORSE WWE AND KENDALL JR AW. 1993. A comparison of larval fish assemblages in the temperate zone of northeast Pacific and the northwest Atlantic Ocean. Bull Mar Sci 53: 588-644.

EKAU W AND KNOPPERS B. 1999. An introduction to the pelagic system of the north-east and east Brazilian shelf. Arch Fish Mar Res 47: 113-132.

FAHAY MP. 1983. Guide to the early stages of marine fishes occurring in the western North Atlantic Ocean, Cape Hatteras to the southern Scotian Shelf. J Northwest Atl Fish Sci 4: 1-423.

FLORES-COTO C AND SANCHEZ-RAMIREZ M. 1989. Larval distribution and abundance of Carangidae (Pisces), from the southern Gulf of Mexico. Gulf Caribb Res 8: 117128.

FRANCO-GORDO C, GODÍNEZ-DOMÍNGUEZ E AND SUÁREZ-MORALEZ E. 2002. Larval fish assemblages in waters off central Pacific coast of Mexico. J Plankton Res 24: 775-784.

FREITAS DM AND MUELBERT JH. 2004. Ichthyoplankton distribution and abundance off southeastern and southern Brazil. Braz Arch Biol Technol 47: 601-612.

FONTENEAU A. 1991. Monts sous-marins et thons dans l'Atlantic tropical est. Aquat Living Resour 4: 13-25.

GAUGHAN DJ, NEIRA FJ, BECKLEY LE AND POTTER IC. 1990. Composition, seasonality and distribution of the Ichthyoplankton in the lower Swan estuary, south-western Australia. Mar Freshwater Res 41: 529-543.

KEEKLER D. 1995. SURFER for Windows. Version 6. User's Guide.

LESSA RP, MAFALDA JR PO, ADVÍNCULA R, LUCCHESI RB, BEZERRA JR JL, VASKE JR T AND HELLEBRANDT D. 1999. Distribution and abundance of ichthyoneuston at seamounts and islands off north-eastern Brazil. Arch Fish Mar Res 47: 239-252.

LONGHURST A. 1985. Relationship between diversity and the vertical structure of the upper ocean. Deep Sea Res 32: $1535-1570$.

LOPES R, KATSURAGAWAM, DIAS JF, MONTU MA AND MUELBERT JH. 2006. Zooplankton and ichthyoplankton distribution on the southern Brazilian shelf: an overview. Sci Mar 70: 189-202.

MACEDO-SOARES LCP, GARCIA CAE, FREIRE AS AND MUELBERT JH. 2014. Large-Scale Ichthyoplankton and 
Water Mass Distribution along the South Brazil Shelf. PLoS One 9: e91241.

MAFALDA JR P AND RUBÍN JP. 2006. Interannual variation of larval fish assemblages in the Gulf of Cádiz (SW Iberian Peninsula) in relation to summer oceanographic conditions. Braz Arch Biol Technol 49: 287-296.

MOYANO M AND HERNÁNDEZ-LEÓN S. 2011. Intra- and interannual variability in the larval fish assemblage off Gran Canaria (Canary Islands) over 2005-2007. Mar Biol 158: 257-273.

MOYANO M, RODRÍGUEZ JM AND HERNÁNDEZ-LEÓN S. 2009. Larval fish abundance and distribution during the late winter bloom off Gran Canaria Island, Canary Islands. Fish Oceanogr 18: 51-61.

MOYLE PB AND CECH JR JJ. 1982. An Introduction to Ichthyology. Prentice-Hall, Englewood Clifs, 593 p.

MOSER HG AND SMITH PE. 1993. Larval fish assemblage and oceanic boundaries. Bull Mar Sci 53: 283-289.

MUHLING BA, BECKLEY LE, KOSLOW JAAND PEARCE AF. 2008. Larval fish assemblages and water mass structure off the oligotrophic south-western Australian coast. Fish Oceanogr 17: 16-31.

NELLEN W. 1974. Investigations on the distribution of fish larvae and plankton near and above the Great Meteor Seamount. In: Blaxter JH (Ed), The Early Life History of Fish. Springer-Verlag, New York, p. 213-214.

NELSON JS. 1994. Fishes of the World. John Wiley \& Sons, New York, 599 p.

NONAKA RH, MATSUURA Y AND SUZUKI K. 2000. Seasonal variation in larval fish assemblages in relation to oceanographic conditions in the Abrolhos Bank region off eastern Brazil. Fish Bull 98: 767-784.

OMORI M AND IKEDA T. 1984. Methods in marine zooplankton ecology. John Wiley \& Sons, New York, 332 p.

QUEIROZ AR, MONTES MF, MELO PA, SILVA RA AND KOENING ML. 2015. Vertical and horizontal distribution of phytoplankton around an oceanic archipelago of the Equatorial Atlantic. Mar Biodivers Rec 8: 2015.

RAKOCINSKI CF, BALTZ DM AND FLEEGER JW. 1995. Correspondence between environmental gradients and the community structure of marsh-edge fishes in a Louisiana estuary. Mar Ecol Prog Ser 80: 135-148.

RICHARDS WJ, MCGOWAN MF, LEMING T, LAMKIN JT AND KELLEY S. 1993. Larval fish assemblages at the loop current boundary in the Gulf of Mexico. Bull Mar Sci 53: 475-537.

RÖPKE A. 1993. Do larvae of mesopelagic fishes in the Arabian Sea adjust their vertical distribution to physical and biological gradients? Mar Ecol Prog Ser 101: 223-235.

SMITH PE AND RICHARDSON SL. 1977. Standard techniques for pelagic fish eggs and larvae surveys. FAO Fish Tech Pap 175: 1-100.

SOUZA CS, LUZ JA, MACEDO S, MONTES MJF AND MAFALDA JR PO. 2013. Chlorophyll $a$ and nutrient distribution around seamounts and islands of the tropical south-western Atlantic. Mar Freshwater Res 64: 168-184.

SOUZA CS AND MAFALDA JR PO. 2008. Distribution and Abundance of Carangidae (Teleostei, Perciformes) Associated with Oceanographic Factors along the Northeast Brazilian Exclusive Economic Zone. Braz Arch Biol Technol 51: 1267-1278.

STRICKLAND JDH AND PARSONS TR. 1972. A Practical Handbook of Seawater Analyses, $2^{\text {nd }}$ ed., Fisheries Research Board of Canada, $310 \mathrm{p}$.

TER BRAK CJF AND SMILAUER P. 2002. CANOCO reference manual and CanoDraw for Windows user's guide: software for canonical community ordination (version 4.5). Microcomputer Power, Ithaca, New York, USA.

TRAVASSO P, HAZIN FHV, ZAGAGLIA J, ADVÍNCULA R AND SCHOBER J. 1999. Thermohaline structure around seamounts and islands off North-Eastern Brazil. Arch Fish Mar Res 47: 211-222.

WHITFIELD AK AND PATERSON AW. 2003. Distribution patterns of fishes in a freshwater deprived Eastern Cape estuary, with particular emphasis on the geographical headwater region. Water SA 29: 61-67.

YOKLAVICH MM, STEVENSON M AND CAILLIET GM. 1992. Seasonal and spatial patterns of ichthyoplankton abundance in Elkhorn Slough, California. Estuar Coast Shelf Sci 34: 109-126. 